\title{
Effect of pruning-derived biochar on heavy metals removal and water dynamics
}

\section{Antonio G. Caporale, Massimo Pigna, Alessia Sommella \& Pellegrino Conte}

Biology and Fertility of Soils

Cooperating Journal of International Society of Soil Science

ISSN 0178-2762

Biol Fertil Soils

DOI 10.1007/s00374-014-0960-5

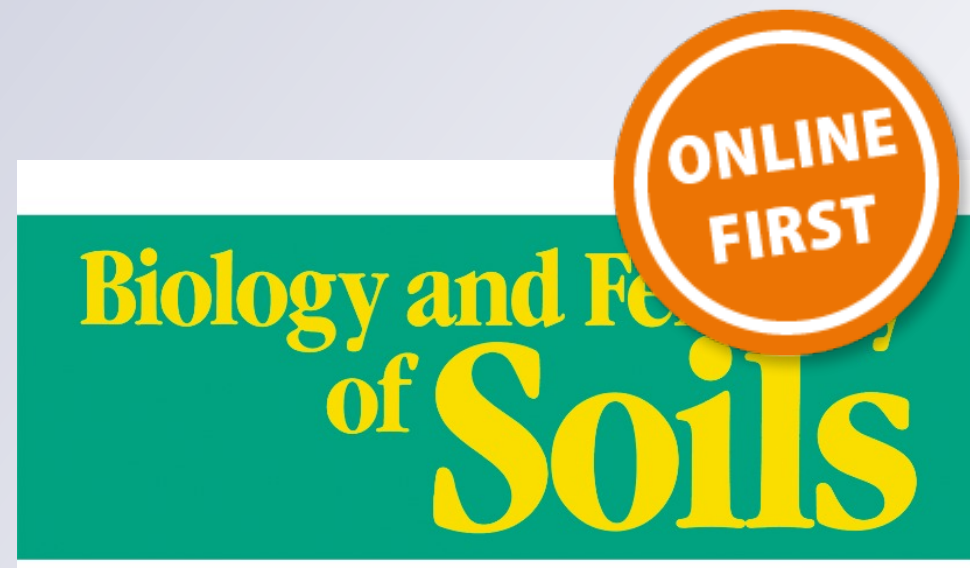

Volume 50 • Number 7 • October 2014

Short-term effect of tillage and crop rotation
on microbial community structure and enzyme on microbial community structure and enzyme
activities of a clay loam soil B. Than 1077

Effect of biochar on aerobic processes, enzyme
activity, and crop yields in two sandy loam soils activity, and crop yields in two sandy loam soils
Z. Sun. E.W. Brunn. E. Arthur L. W. de Jonge.
P. Moldrup . H. Hauggaard-Nielsen . L. Elsgaaard 1087

Changes in weathering effectiveness and
community of culturable mineral-weathering bacteria along a soil profile

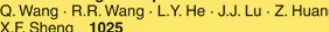

Plant growth responses to biochar addition
an Australian soils perspective L.M. Macdonald · M. Farrell · L.V. Zwieten

Clay addition to lime-amended biosolids overcomes water repellence and provides nitrogen supply S. Shanmugam . L.K. Abbott - D.V. Murphy 1047 Effect of preceding crops and their residues on H. Habiby - M. Afyuni - A.H. Khoshgoftarmanesh. R. Schulin 1061

Microbial community development and unseen diversity recovery in inoculated sterile sol A. Mathieu - J. Nesme - M.T. Ceccherini - P. Nannipieri P. Simonet - T.M. Vogel 1069

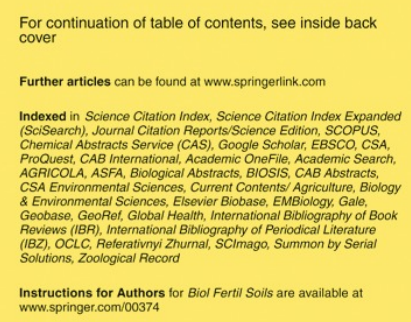

算 Springer 
Your article is protected by copyright and all rights are held exclusively by SpringerVerlag Berlin Heidelberg. This e-offprint is for personal use only and shall not be selfarchived in electronic repositories. If you wish to self-archive your article, please use the accepted manuscript version for posting on your own website. You may further deposit the accepted manuscript version in any repository, provided it is only made publicly available 12 months after official publication or later and provided acknowledgement is given to the original source of publication and a link is inserted to the published article on Springer's website. The link must be accompanied by the following text: "The final publication is available at link.springer.com". 


\title{
Effect of pruning-derived biochar on heavy metals removal and water dynamics
}

\author{
Antonio G. Caporale • Massimo Pigna • \\ Alessia Sommella $\cdot$ Pellegrino Conte
}

Received: 8 June 2014 /Revised: 28 August 2014 / Accepted: 15 September 2014

(C) Springer-Verlag Berlin Heidelberg 2014

\begin{abstract}
Biomass-derived biochar is considered as a promising heavy metal adsorbent, due to abundance of polar functional groups, such as carboxylic, hydroxyl, and amino groups, which are available for heavy metal removal. The aims of this study were to evaluate the effectiveness of an orchard pruning-derived biochar in removing some heavy metals (through the evaluation of isotherms) and to study water dynamics at the solid-liquid interface as affected by heavy metal adsorption (through an innovative nuclear magnetic resonance (NMR) relaxometry approach). Both isotherms and NMR spectra revealed that $\mathrm{Pb}$ and $\mathrm{Cr}$ showed a good affinity for the biochar surface $(\mathrm{Pb}>\mathrm{Cr}$ ), while $\mathrm{Cu}$ was less affine. Accordingly, higher amounts of $\mathrm{Pb}$ and $\mathrm{Cr}$ were adsorbed by biochar as compared to those of $\mathrm{Cu}$ in the single systems. In binary systems (i.e., when two metals were applied simultaneously), $\mathrm{Pb}$ showed the highest inhibition of the adsorption of the other two metals, whereas the opposite was evidenced when $\mathrm{Cu}$ was used; the competitive adsorption was also strongly influenced by the metal residence time on biochar surface. In ternary systems (i.e., when all metals were applied simultaneously), even in the presence of high amounts of $\mathrm{Pb}$ and $\mathrm{Cr}$, considerable adsorption of $\mathrm{Cu}$ occurred, indicating that some biochar adsorption sites were highly specific for a single metal.
\end{abstract}

Keywords Biochar $\cdot$ Heavy metals $\cdot$ Lead $\cdot$ Chromium $\cdot$ Copper $\cdot$ Water dynamics $\cdot$ NMR relaxometry

A. G. Caporale $(\varangle) \cdot$ M. Pigna $\cdot$ A. Sommella Dipartimento di Agraria, Università degli Studi di Napoli Federico II, Via Università 100, 80055 Portici, NA, Italy

e-mail: ag.caporale@unina.it

P. Conte

Dipartimento di Scienze Agrarie e Forestali, Università degli Studi di Palermo, V.le delle Scienze edificio 4, 90128 Palermo, Italy

\section{Introduction}

Heavy metals, such as lead $(\mathrm{Pb})$, chromium $(\mathrm{Cr})$, and copper $(\mathrm{Cu})$ pose a risk to public health because of their toxic and non-biodegradable nature and widespread occurrence in natural and human-altered environments (Inyang et al. 2012; Regmi et al. 2012). They are mainly introduced into aquatic environments from point sources as discharges from mining, metal processing, tanneries, pharmaceuticals, pesticides, organic chemicals, rubber and plastics, and lumber and wood products (Shi et al. 2009). Conventional technologies for the removal and recovery of heavy metals from wastewaters include chemical precipitation, ion exchange, electrochemistry removal, membrane separation, microbe separation, adsorption by activated carbon, and so on (Srivastava and Majumder 2008). However, most of these methods suffer from some drawbacks, such as high capital, high operational cost, and the disposal of resulting sludge. Therefore, it is needed to develop a novel method, which is not only costeffective but also readily implemented. Adsorption appears to be a good choice if a low-cost adsorbent is applied (Shi et al. 2009). Biomass-derived biochar is considered as a promising heavy metal adsorbent (Mohan et al. 2007; Qiu et al. 2008; Liu and Zhang 2009; Beesley and Marmiroli 2011; Li et al. 2013), due to abundance of polar functional groups, such as carboxylic, hydroxyl, and amino groups, which are available for heavy metal removal (Cao et al. 2009; Hsu et al. 2009; Wang et al. 2010). Biochar is a fine-grained carbonaceous solid residue, produced by pyrolysis of carbon-rich biomass under oxygen-limited conditions (Chen et al. 2011; Xu et al. 2013). In recent years, biochar has also received considerable interest as a large-scale soil amendment to enhance crop productivity and soil fertility (Major et al. 2010; Vaccari et al. 2011; Farrell et al. 2014; Prayogo et al. 2014; Song et al. 2014), to increase soil water holding capacity (Kammann et al. 2011; Baronti et al. 2014), to decrease nutrient leaching 
(Laird et al. 2010), and to serve as a recalcitrant carbon stock (Lehmann 2007a, b; Laird 2008) to potentially mitigating climate changes (Conte et al. 2013; Cimò et al. 2014) by reducing greenhouse gas emissions (Castaldi et al. 2011; Stewart et al. 2013). Biochar has many properties, such as a relatively structured carbon matrix, high degree of microporosity, extensive surface area, and high $\mathrm{pH}$ and cation exchange capacity (CEC); therefore, it may act as a surface adsorbent (Jiang et al. 2012a, b). Given that it is highly recalcitrant, the beneficial effects of its application may be prolonged over a long period of time (Fellet et al. 2011; De Pasquale et al. 2012). Charred biomasses, on the other hand, are estimated to have mean residence times of thousands of years in soils (Lehmann et al. 2008). Many studies have investigated the adsorption of $\mathrm{Pb}, \mathrm{Cr}$, and $\mathrm{Cu}$ on biochar in single sorbate systems (Liu and Zhang 2009; Mohan et al. 2011; Tong et al. 2011; Lu et al. 2012; Shen et al. 2012; Li et al. 2013). However, as metals usually coexist in the environment and undergo competitive sorption (Zhu et al. 2010; Chen et al. 2011), the study of systems with a mixture of contaminants is paramount. In the present study, we studied the following: (i) $\mathrm{Pb}, \mathrm{Cr}$, and $\mathrm{Cu}$ adsorption capacities of a commercial orchard pruning-derived biochar, at $\mathrm{pH} 4.5$ and $20^{\circ} \mathrm{C}$, in single sorbate systems; (ii) the competitive adsorption of metals in binary and ternary systems, affected by their initial concentration and residence time on biochar surface; and (iii) the water molecular dynamics on the surface of the porous biochar, as affected by metal adsorption, by fast-fieldcycling nuclear magnetic resonance (NMR) relaxometry. The latter technique allowed us to investigate the water movement inside biochar pores through the measurement of the longitudinal relaxation times $\left(T_{1}\right)$, which provide information on the way as water molecules are constricted in a porous media. Knowledge of water movement in porous media containing adsorbed metals is very important in order to understand the role of metals in the nutrient transport toward plant roots. In addition, the study of water movements in biochar pores, before and after $\mathrm{Pb}, \mathrm{Cr}$, and/or $\mathrm{Cu}$ adsorption is also useful for the recognition of the nature of biochar-metal bonds at the solid-liquid interface.

\section{Materials and methods}

\section{Biochar collection}

The orchard pruning-derived biochar applied in the present study is a commercial charcoal made by Romagna Carbone snc (Italy), obtained from orchard pruning biomass through a slow pyrolysis process at temperature of $500{ }^{\circ} \mathrm{C}$, in a transportable ring kiln of $2.2 \mathrm{~m}$ in diameter and holding around $2 \mathrm{t}$ of feedstock. The biochar at the end of the pyrolysis was crushed into $<5-\mathrm{cm}$ particles before selling (Baronti et al. 2014). A suitable amount of this biochar was allowed to airdry, milled in a china mortar, and subsequently passed through a sieve having $500 \mu \mathrm{m}$ of pore diameters, in order to obtain an homogeneous sample for adsorption experiments and NMR relaxometry investigations.

\section{Biochar characterization}

In order to determine the functional groups in the biochar sample, the Fourier transform infrared (FT-IR) spectrum was acquired in the range of $400-4000 \mathrm{~cm}^{-1}$ by Perkin-Elmer Frontier FT-IR/NIR Spectrometer (Perkin Elmer USA), with a spectral resolution of $1 \mathrm{~cm}^{-1}$.

\section{NMR relaxometry investigations}

All samples were first suspended in deionized water, then analyzed by a Stelar Spinmaster Fast Field Cycling Relaxometry instrument at a constant temperature of $25^{\circ} \mathrm{C}$. The bases for the FFC NMR relaxometry have been reported by Conte and Alonzo (2013). For this reason, here, we only report the experimental conditions applied in the present study. Namely, all experiments were conducted at the fixed relaxation field ( $\left.B_{\mathrm{RLX}}\right)$ of $0.5 \mathrm{~T}$, with the period $\tau$, during which $B_{\mathrm{RLX}}$ was applied, varying on 32 logarithmic spaced time sets; 16 scans were set with a recycle delay of $2 \mathrm{~s}$. No polarization field $\left(B_{\mathrm{POL}}\right)$ has been applied so that all measurements were done in non-polarized (NP) mode. $\mathrm{A}^{1} \mathrm{H} 90^{\circ}$ pulse was applied at an acquisition field $\left(B_{\mathrm{ACQ}}\right)$ of $0.18 \mathrm{~T}$ in order to retrieve the free induction decay (FID) with a time domain of $100 \mu \mathrm{s}$ and 512 points. Field switching time was $3 \mathrm{~ms}$, while spectrometer dead time was $15 \mu \mathrm{s}$. All recovery curves were evaluated by the UPEN algorithm (Alma Mater Studiorum, Università di Bologna, Italy) (Conte and Alonzo 2013) with the aim to obtain the longitudinal relaxation time $\left(T_{1}\right)$ distributions, and therefore, information on the way water molecules are trapped in each sample (Conte et al. 2013). The $T_{1}$ distribution curves were exported to OriginPro 7.5 SR6 (version 7.5885, OriginLab Corporation, Northampton, MA, USA) in order to perform deconvolution with Gaussian functions and to recover the different components giving rise to the longitudinal relaxation time distributions. The Gaussian curves were combined to obtain the best fitting of experimental data. Deconvolution was considered optimum when the coefficient of determination $\left(R^{2}\right)$ for the best fitting resulted $\geq 0.98$.

\section{Adsorption isotherms}

Suitable volumes of $50 \mathrm{mmol} \mathrm{L}^{-1}$ solutions containing $\mathrm{Pb}$ as $\mathrm{Pb}^{\mathrm{II}}\left(\mathrm{NO}_{3}\right)_{2}, \mathrm{Cr}$ as $\mathrm{Cr}^{\mathrm{III}}\left(\mathrm{NO}_{3}\right)_{3}$, or $\mathrm{Cu}$ as $\mathrm{Cu}^{\mathrm{II}}\left(\mathrm{NO}_{3}\right)_{2}$ (SigmaAldrich, USA) were added to $100 \mathrm{mg}$ of biochar samples in 
50-mL conical flasks. Initial $\mathrm{Pb}$ and $\mathrm{Cr}$ concentrations ranged from 0.05 to $1.0 \mathrm{mmol} \mathrm{L}^{-1}$, whereas $\mathrm{Cu}$ concentration ranged from 0.03 to $0.75 \mathrm{mmol} \mathrm{L}^{-1}$. The final volume was adjusted to $20 \mathrm{~mL}$ with $1.0 \mathrm{mM} \mathrm{KNO}_{3}$, in order to have an initial biochar/ solution ratio of $5 \mathrm{~g} \mathrm{~L}^{-1}$. The $\mathrm{pH}$ of each suspension was kept constant at 4.5 for $5 \mathrm{~h}$ at $20^{\circ} \mathrm{C}$ by adding $10 \mathrm{mM} \mathrm{HNO}_{3}$ or $10 \mathrm{mM} \mathrm{KOH}$ using an automatic titrator (Potentiograph E536 Metrom Herisau) connected to an automatic syringe (burette 655 Dosimat). The operation was done in order to avoid metal precipitation, which can occur at $\mathrm{pH}$ values higher than 4.5 (Zhu et al. 2010). The final suspension was centrifuged at $10,000 \mathrm{~g}$ for $20 \mathrm{~min}$ and filtered through Nalgene acetate membrane (pore size $<0.22 \mu \mathrm{m}$ ). The concentration of metals in the final solution was determined by flame atomic adsorption spectrometry using a Perkin-Elmer AAnalist 700. The adsorption of metals by biochar was calculated by the difference between the amounts of metals initially added and those remained in the supernatant; in preliminary experiments, the washing after metal adsorption removed negligible amounts of metals.

Competitive adsorption in binary and ternary systems

Competitive adsorption of $\mathrm{Pb}, \mathrm{Cr}$, and $\mathrm{Cu}$ in binary systems was observed at $\mathrm{pH} 4.5$, by adding simultaneously $\mathrm{Pb}$ and $\mathrm{Cr}$, $\mathrm{Pb}$ and $\mathrm{Cu}$, or $\mathrm{Cr}$ and $\mathrm{Cu}$ to $100 \mathrm{mg}$ of biochar samples in $50-\mathrm{mL}$ conical flasks. The concentration of $\mathrm{Pb}$ or $\mathrm{Cr}$ in the $\mathrm{Pb}-$ Cr binary system ranged from 25 to $75 \mathrm{mmol} \mathrm{kg}^{-1}$, whereas the concentration of $\mathrm{Pb}, \mathrm{Cr}$, or $\mathrm{Cu}$ in the $\mathrm{Pb}-\mathrm{Cu}$ and $\mathrm{Cr}-\mathrm{Cu}$ binary systems ranged from 20 to $60 \mathrm{mmol} \mathrm{kg}^{-1}$, so as to have initial $\mathrm{Pb} / \mathrm{Cr}, \mathrm{Pb} / \mathrm{Cu}$, or $\mathrm{Cr} / \mathrm{Cu}$ molar ratios $\left(R_{i}\right)$ ranging between 0.33 and 3.0. Experiments were also carried out by adding a metal $(\mathrm{Pb}, \mathrm{Cr}$, or $\mathrm{Cu})$ to $100 \mathrm{mg}$ of biochar $1 \mathrm{~h}$ before the second metal, and then the metal mixture was incubated with biochar for $5 \mathrm{~h}$ at $\mathrm{pH} 4.5$ and $20^{\circ} \mathrm{C}$, so as to evaluate the relationships between the metal residence time and the biochar adsorption capacity. Competitive adsorption of $\mathrm{Pb}, \mathrm{Cr}$, and $\mathrm{Cu}$ in ternary systems was investigated at $\mathrm{pH} 4.5$, by adding simultaneously $\mathrm{Pb}, \mathrm{Cr}$, and $\mathrm{Cu}$ to $100 \mathrm{mg}$ of biochar samples in $50-\mathrm{mL}$ conical flasks. The concentration of each metal ranged from 20 to $60 \mathrm{mmol} \mathrm{kg}$, with different initial $\mathrm{Pb} / \mathrm{Cr} / \mathrm{Cu}$ molar ratios. The final volume of each suspension of binary and ternary systems was adjusted to $20 \mathrm{~mL}$ with $1.0 \mathrm{mM} \mathrm{KNO}_{3}$, in order to have an initial biochar/solution ratio of $5 \mathrm{~g} \mathrm{~L}^{-1}$. The $\mathrm{pH}$ was kept constant at 4.5 for $5 \mathrm{~h}$ at $20^{\circ} \mathrm{C}$ by adding $10 \mathrm{mM} \mathrm{HNO}_{3}$ or $10 \mathrm{mM} \mathrm{KOH}$ using an automatic titrator (Potentiograph E536 Metrom Herisau) connected to an automatic syringe (burette 655 Dosimat). The final suspension was centrifuged at $10,000 \mathrm{~g}$ for $20 \mathrm{~min}$ and filtered through Nalgene acetate membrane (pore size $<0.22 \mu \mathrm{m}$ ). The supernatant was collected, and the concentration of heavy metals was determined as described above.
Table 1 FT-IR assignments

\begin{tabular}{ll}
\hline Wavenumber $\left(\mathrm{cm}^{-1}\right)$ & Possible assignments \\
\hline 3,546 & $\begin{array}{c}\text { Oxydrils and unsubstituted amides } \\
\text { involved in H bonds } \\
\text { N-monosubstituted amides }\end{array}$ \\
3,470 & $-\mathrm{NH}$ in amine groups \\
3,413 & $\mathrm{C}-\mathrm{H}$ in aromatic compounds \\
$3,232,3,118,2,034$ & $\mathrm{NN}-$ disubstituted amides \\
1,637 & Carboxylate groups \\
$1,617,1,400$ & $\mathrm{C}-\mathrm{O}$ groups \\
1,126 &
\end{tabular}

\section{Results}

Nature of the biochar

The physicochemical properties of the pruning-derived biochar have been described by Baronti et al. (2014). The total biochar porosity was $2,722 \mathrm{~mm}^{3} \mathrm{~g}^{-1}$, while the specific surface area resulted $410 \pm 6 \mathrm{~m}^{2} \mathrm{~g}^{-1}$. Moreover, three kinds of pores was identified: transmission $(\geq 50 \mu \mathrm{m})$, storage $(0.5-50 \mu \mathrm{m})$, and residual $(<0.5 \mu \mathrm{m})$ pores, which accounted for 10,75 , and $15 \%$ of the total porosity, respectively. Table 1 reports the main FT-IR bands with all the possible assignments of the functional groups present in the biochar. In addition, the physical properties of biochar and the heavy metal contaminated biochar have been investigated by low field ${ }^{1} \mathrm{H}$ NMR relaxometry with fast field cycling setup. Figures 1, 2, 3, and 4 report all the proton longitudinal relaxation $\left(T_{1}\right)$ distributions.

\section{Adsorption isotherms}

The adsorption isotherms of $\mathrm{Pb}, \mathrm{Cr}$, and $\mathrm{Cu}$, added individually onto biochar samples at $\mathrm{pH} 4.5$, are shown in Fig. 5 and

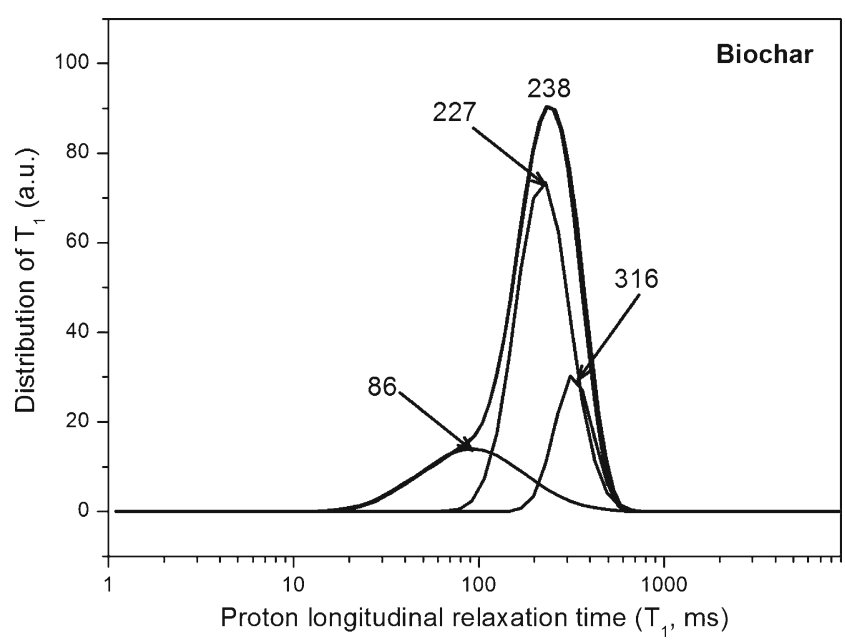

Fig. 1 Longitudinal relaxation times $\left(T_{1}\right)$ : distribution of the sole biochar 
Fig. 2 Longitudinal relaxation times $\left(T_{1}\right)$ : distributions of Cu-adsorbed (a), Cr-adsorbed (b), and $\mathrm{Pb}$-adsorbed (c) biochar samples
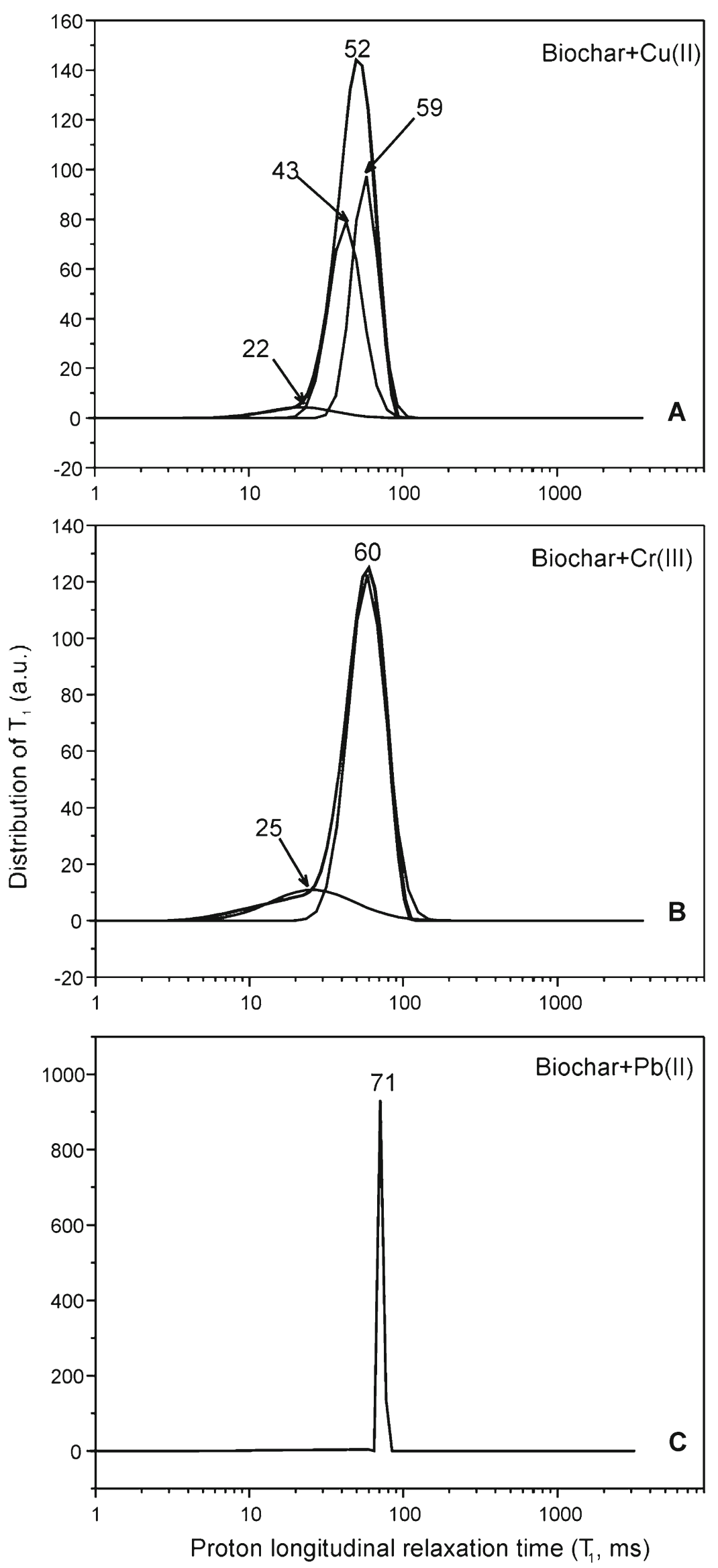
Fig. 3 Longitudinal relaxation times $\left(T_{1}\right)$ : distributions of $\mathrm{Cu}, \mathrm{Cr}$-adsorbed (a), $\mathrm{Cr}, \mathrm{Pb}$ adsorbed (b), and $\mathrm{Cu}, \mathrm{Pb}-$ adsorbed (c) biochar samples
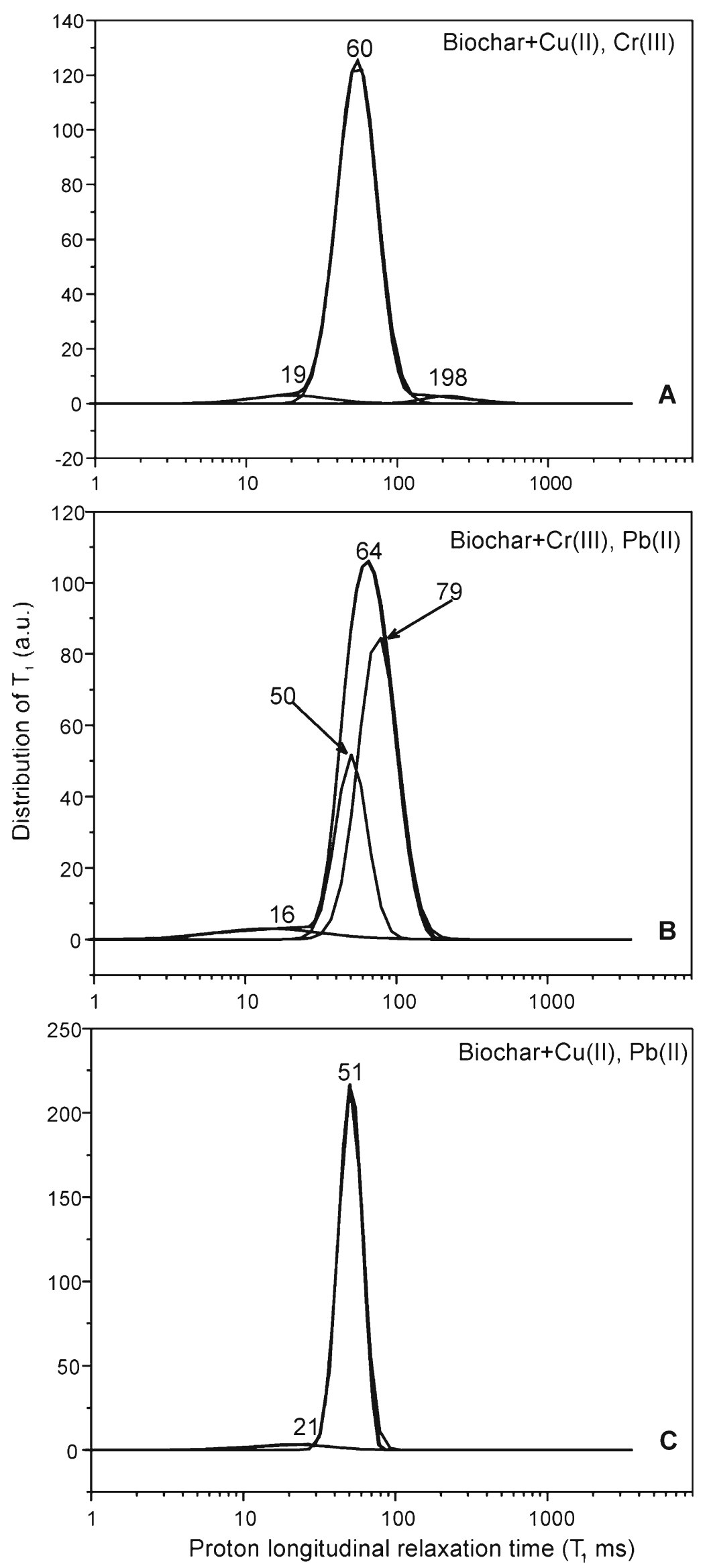


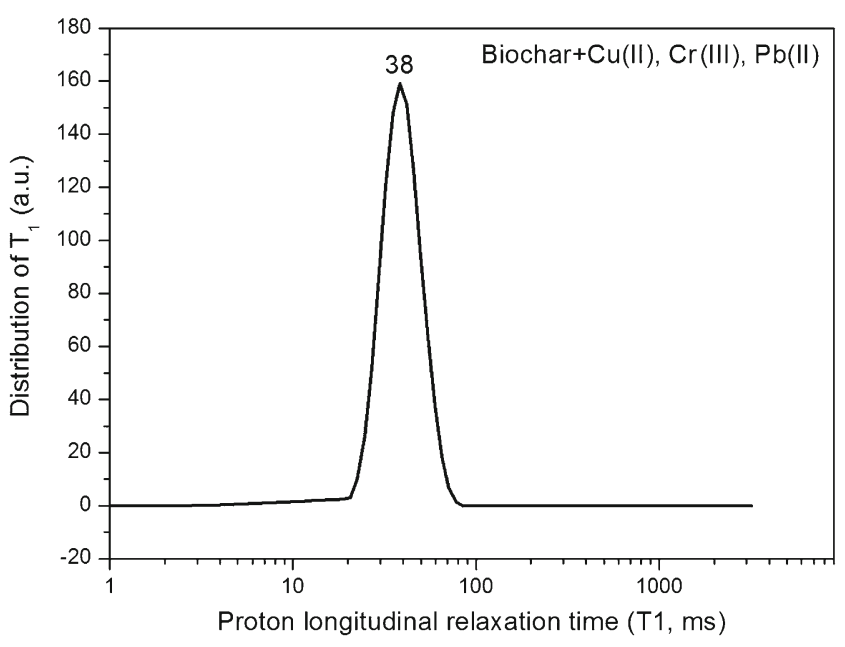

Fig. 4 Longitudinal relaxation times $\left(T_{1}\right)$ : distribution of $\mathrm{Cu}, \mathrm{Cr}, \mathrm{Pb}$ adsorbed biochar

described by Langmuir equation: $S=S_{m} K c /(1+K c)$, where $S$ is the amount of each metal adsorbed per unit mass of adsorbent $\left(\mathrm{mmol} \mathrm{kg}^{-1}\right), S_{m}$ is the maximum amount that may be bound to the adsorbent (adsorption capacity) (Table 2), $c$ is the equilibrium concentration $\left(\mathrm{mmol} \mathrm{L}^{-1}\right)$, and $K$ is a constant related to the binding energy (Table 2).

\section{Competitive adsorption of $\mathrm{Pb}, \mathrm{Cr}$, and $\mathrm{Cu}$ in binary systems}

The competitive adsorption of $\mathrm{Pb}$ vs. $\mathrm{Cr}, \mathrm{Pb}$ vs. $\mathrm{Cu}$, and $\mathrm{Cr}$ vs. $\mathrm{Cu}$ on biochar was reported in Tables 3, 4, and 5, respectively. In the binary systems, $\mathrm{Pb}$ showed the highest inhibition of the adsorption of the other two metals, with a reduction of $\mathrm{Cr}$ and $\mathrm{Cu}$ adsorption on biochar surface by 36.2 and $73.5 \%$, respectively, as compared to the amounts adsorbed from single sorbate systems (Tables 3 and 4). Chromium also strongly

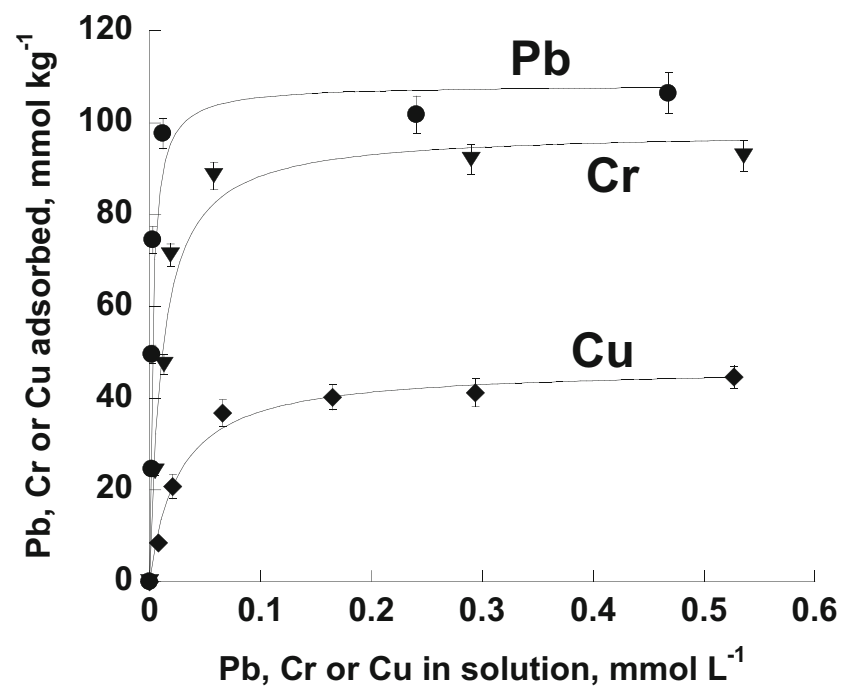

Fig. 5 Adsorption isotherms of $\mathrm{Pb}, \mathrm{Cr}$, and $\mathrm{Cu}$ on biochar at $\mathrm{pH} 4.5$ and $20^{\circ} \mathrm{C}$, after $5 \mathrm{~h}$ of reaction time.
Table 2 Langmuir adsorption capacities $\left(S_{m}\right)$ and $K$ constant for $\mathrm{Pb}, \mathrm{Cr}$, and $\mathrm{Cu}$, as obtained from the adsorption isotherms of the biochar at $\mathrm{pH}$ 4.5 and $20^{\circ} \mathrm{C}$, after $5 \mathrm{~h}$ of reaction time

\begin{tabular}{llll}
\hline Heavy metal & $S_{m}\left(\mathrm{mmol} \mathrm{kg}^{-1}\right)$ & $K$ & $R^{2}$ \\
\hline $\mathrm{Pb}$ & $108.2(0.264)$ & 21.4 & 0.97 \\
$\mathrm{Cr}$ & $98.3(0.240)$ & 15.8 & 0.96 \\
$\mathrm{Cu}$ & $46.5(0.113)$ & 4.5 & 0.99 \\
\hline
\end{tabular}

Numbers in brackets indicate the amount of $\mathrm{Pb}, \mathrm{Cr}$, and $\mathrm{Cu}$ adsorbed as $\mu \mathrm{mol} \mathrm{m}{ }^{-2}$. Specific surface area $\left(410 \mathrm{~m}^{2} \mathrm{~g}^{-1}\right)$ of biochar was determined by Baronti et al. (2014), by the dynamic Brunauer-Emmett-Teller (BET) method with $\mathrm{N}_{2}$ as adsorbate

inhibited $\mathrm{Cu}$ adsorption on biochar because of its greater adsorption affinity (Table 5). The presence of many highaffinity adsorption sites for $\mathrm{Pb}$ and $\mathrm{Cr}$ on biochar surface determined a relatively low inhibition of metal adsorption by biochar, in the $\mathrm{Pb}-\mathrm{Cr}$ binary system (Table 3 ), especially at the lowest concentration $\left(25 \mathrm{mmol} \mathrm{kg}^{-1}\right)$.

Effect of metal residence time on biochar adsorption capacity

The adsorption of $\mathrm{Pb}, \mathrm{Cr}$, and $\mathrm{Cu}$ on biochar in binary systems was also affected by metal residence time on biochar surface (Figs. 6, 7, and 8). Unlike the binary systems described above, where two metals were simultaneously added to biochar samples, here, the first metal was added $1 \mathrm{~h}$ before the second metal, followed by incubation of the metal mixture with biochar for $5 \mathrm{~h}$ at $\mathrm{pH}$ 4.5. We found that the adsorption of the first metal added on biochar was higher if compared to that obtained with the simultaneous addition of two metals, whereas the opposite was shown for the second metal added to the system (Figs. 6, 7, and 8); we also noted that the intensity of change in adsorption of three metals was strictly related to the affinity of these toxicants for biochar surface. When $\mathrm{Pb}$ was added as first metal, we observed that its adsorption on biochar increased more intensely than adsorption of the other two metals; vice versa, when $\mathrm{Pb}$ was added as second metal, its adsorption decreased to a lesser extent if compared to those of $\mathrm{Cr}$ and $\mathrm{Cu}$ (Figs. 6, 7, and 8). Being the kinetics of $\mathrm{Pb}, \mathrm{Cr}$, and $\mathrm{Cu}$ adsorption very fast (around the $80-90 \%$ of the metal initially added was adsorbed by biochar in the first hour of reaction, followed by a much slower adsorption rate in the subsequent $4 \mathrm{~h}$ with negligible adsorption after $5 \mathrm{~h}$ ) (data not shown), it is conceivable that the first metal added on biochar surface readily occupied most of the adsorption sites.

Competitive adsorption of $\mathrm{Pb}, \mathrm{Cr}$, and $\mathrm{Cu}$ in ternary systems

Competitive adsorption studies were also carried out by adding $\mathrm{Pb}, \mathrm{Cr}$, and $\mathrm{Cu}$ simultaneously on biochar samples at pH 4.5 (Table 6). When equimolar amounts of each metal were initially added $\left(20,40\right.$, or $\left.60 \mathrm{mmol} \mathrm{kg}^{-1}\right)$ to biochar, the 
Table 3 Competitive adsorption of $\mathrm{Pb}$ and $\mathrm{Cr}$ on biochar at $\mathrm{pH} 4.5$ and $20^{\circ} \mathrm{C}$, after $5 \mathrm{~h}$ of incubation

\begin{tabular}{|c|c|c|c|c|c|c|c|}
\hline \multicolumn{2}{|c|}{ Added amounts $\left(\mathrm{mmol} \mathrm{kg}^{-1}\right)$} & \multicolumn{2}{|c|}{ Adsorbed amounts (mmol kg ${ }^{-1}$ ) } & \multirow{2}{*}{$\begin{array}{l}\text { Initial ratio }\left(R_{i}\right)^{\mathrm{a}} \\
\mathrm{Pb} / \mathrm{Cr}\end{array}$} & \multirow[t]{2}{*}{ Final ratio $\left(R_{f}\right)^{\mathrm{b}}$} & \multicolumn{2}{|c|}{ Adsorption inhibition (\%) } \\
\hline $\mathrm{Pb}$ & $\mathrm{Cr}$ & $\mathrm{Pb}$ & $\mathrm{Cr}$ & & & $\mathrm{Pb}$ & $\mathrm{Cr}$ \\
\hline 25 & 25 & $23 \pm 1$ & $20.4 \pm 0.9$ & 1.00 & 1.12 & 7.4 & 11.2 \\
\hline 25 & 50 & $22 \pm 1$ & $38 \pm 2$ & 0.50 & 0.56 & 12.4 & 15.3 \\
\hline 25 & 75 & $19.8 \pm 0.9$ & $57 \pm 4$ & 0.33 & 0.35 & 19.4 & 17.1 \\
\hline 50 & 25 & $43 \pm 2$ & $19 \pm 1$ & 2.00 & 2.32 & 12.6 & 18.3 \\
\hline 50 & 50 & $42 \pm 2$ & $36 \pm 2$ & 1.00 & 1.18 & 15.8 & 21.4 \\
\hline 50 & 75 & $39 \pm 3$ & $53 \pm 4$ & 0.67 & 0.74 & 20.7 & 22.6 \\
\hline 75 & 25 & $61 \pm 3$ & $17.3 \pm 0.7$ & 3.00 & 3.52 & 18.0 & 24.3 \\
\hline 75 & 50 & $57 \pm 3$ & $32 \pm 2$ & 1.50 & 1.78 & 23.3 & 28.8 \\
\hline 75 & 75 & $50 \pm 3$ & $44 \pm 3$ & 1.00 & 1.14 & 33.3 & 36.2 \\
\hline
\end{tabular}

Adsorbed amounts of $\mathrm{Pb}$ and $\mathrm{Cr}$ are the average of at least three different replicates $(n=3)$

${ }^{\mathrm{a}} R_{i}$ stands for the $\mathrm{Pb} / \mathrm{Cr}$ molar ratio initially added on biochar samples

${ }^{\mathrm{b}} R_{f}$ indicates the $\mathrm{Pb} / \mathrm{Cr}$ molar ratio finally adsorbed on biochar surface

${ }^{\mathrm{c}}$ Inhibition (\%) of $\mathrm{Pb}$ or $\mathrm{Cr}$ adsorption was calculated by subtracting the amount of $\mathrm{Pb}$ or $\mathrm{Cr}$ adsorbed in presence of the other metal from that adsorbed in the absence of the other metal, divided by the amount adsorbed in the absence of the other metal, multiplied per 100

adsorbing surface was covered by $42.3-53.6 \%$ with $\mathrm{Pb}, 35.5-$ $38.6 \%$ with $\mathrm{Cr}$, and $7.8-22.2 \%$ with $\mathrm{Cu}$ (Table 6). It is noteworthy that even adding an initial $\mathrm{Pb}$ concentration twice or triple higher than that of $\mathrm{Cr}$ and $\mathrm{Cu}(\mathrm{Pb}, \mathrm{Cr}$, and $\mathrm{Cu}$ added amounts of 40, 20, and 20 or 60,20 , and $20 \mathrm{mmol} \mathrm{kg}^{-1}$ ), biochar adsorption sites were still occupied by $\mathrm{Cu}(12.5$ or $6.7 \%$, respectively). Therefore, a significant number of adsorption sites had a high affinity for $\mathrm{Cu}$. However, unlike the other two metals, even in presence of twice or triple concentrations of $\mathrm{Cu}$ than those of $\mathrm{Pb}$ and $\mathrm{Cr}(\mathrm{Pb}, \mathrm{Cr}$, and $\mathrm{Cu}$ added amounts of 20, 20, and 40 or 20,20 , and $60 \mathrm{mmol} \mathrm{kg}^{-1}$ ), the biochar adsorption sites were mostly occupied by $\mathrm{Pb}$ and $\mathrm{Cr}$ than $\mathrm{Cu}$ (Table 6).

\section{Discussion}

\section{FT-IR characterization of biochar}

The used biochar has been obtained through pyrolysis at $500{ }^{\circ} \mathrm{C}$ (see Materials and methods). According to Cimò et al. (2014), pyrolysis at the aforementioned temperature

Table 4 Competitive adsorption of $\mathrm{Pb}$ and $\mathrm{Cu}$ on biochar at $\mathrm{pH} 4.5$ and $20^{\circ} \mathrm{C}$, after $5 \mathrm{~h}$ of incubation

\begin{tabular}{|c|c|c|c|c|c|c|c|}
\hline \multicolumn{2}{|c|}{ Added amounts $\left(\mathrm{mmol} \mathrm{kg}^{-1}\right)$} & \multicolumn{2}{|c|}{ Adsorbed amounts (mmol kg ${ }^{-1}$ ) } & \multirow{2}{*}{$\begin{array}{l}\text { Initial ratio }\left(R_{i}\right)^{\mathrm{a}} \\
\mathrm{Pb} / \mathrm{Cu}\end{array}$} & \multirow[t]{2}{*}{ Final ratio $\left(R_{f}\right)^{\mathrm{b}}$} & \multicolumn{2}{|c|}{ Adsorption inhibition $(\%)$} \\
\hline $\mathrm{Pb}$ & $\mathrm{Cu}$ & $\mathrm{Pb}$ & $\mathrm{Cu}$ & & & $\mathrm{Pb}$ & $\mathrm{Cu}$ \\
\hline 20 & 20 & $19 \pm 1$ & $10.6 \pm 0.4$ & 1.00 & 1.80 & 4.1 & 42.6 \\
\hline 20 & 40 & $18 \pm 1$ & $13.9 \pm 0.7$ & 0.50 & 1.29 & 9.0 & 56.5 \\
\hline 20 & 60 & $17.1 \pm 0.8$ & $14.2 \pm 0.6$ & 0.33 & 1.20 & 13.4 & 65.1 \\
\hline 40 & 20 & $36 \pm 2$ & $9.1 \pm 0.5$ & 2.00 & 3.96 & 8.5 & 50.5 \\
\hline 40 & 40 & $35 \pm 2$ & $12.5 \pm 0.5$ & 1.00 & 2.79 & 11.8 & 61.0 \\
\hline 40 & 60 & $32 \pm 1$ & $13 \pm 0.6$ & 0.67 & 2.49 & 17.8 & 68.2 \\
\hline 60 & 20 & $52 \pm 3$ & $7.7 \pm 0.3$ & 3.00 & 6.66 & 12.4 & 57.9 \\
\hline 60 & 40 & $49 \pm 3$ & $10.2 \pm 0.5$ & 1.50 & 4.82 & 16.0 & 68.0 \\
\hline 60 & 60 & $47 \pm 3$ & $10.8 \pm 0.5$ & 1.00 & 4.32 & 20.6 & 73.5 \\
\hline
\end{tabular}

Adsorbed amounts of $\mathrm{Pb}$ and $\mathrm{Cu}$ are the average of at least three different replicates $(n=3)$

${ }^{\mathrm{a}} R_{i}$ stands for the $\mathrm{Pb} / \mathrm{Cu}$ molar ratio initially added on biochar samples

${ }^{\mathrm{b}} R_{f}$ indicates the $\mathrm{Pb} / \mathrm{Cu}$ molar ratio finally adsorbed on biochar surface

${ }^{\mathrm{c}}$ Inhibition (\%) of $\mathrm{Pb}$ or $\mathrm{Cu}$ adsorption was calculated by subtracting the amount of $\mathrm{Pb}$ or $\mathrm{Cu}$ adsorbed in presence of the other metal from that adsorbed in the absence of the other metal, divided by the amount adsorbed in the absence of the other metal, multiplied per 100 
Table 5 Competitive adsorption of $\mathrm{Cr}$ and $\mathrm{Cu}$ on biochar at $\mathrm{pH} 4.5$ and $20^{\circ} \mathrm{C}$, after $5 \mathrm{~h}$ of incubation

\begin{tabular}{|c|c|c|c|c|c|c|c|}
\hline \multicolumn{2}{|c|}{ Added amounts (mmol kg-1) } & \multicolumn{2}{|c|}{ Adsorbed amounts (mmol kg $\left.{ }^{-1}\right)$} & \multirow{2}{*}{$\begin{array}{l}\text { Initial ratio }\left(R_{i}\right)^{\mathrm{a}} \\
\mathrm{Cr} / \mathrm{Cu}\end{array}$} & \multirow[t]{2}{*}{ Final ratio $\left(R_{f}\right)^{\mathrm{b}}$} & \multicolumn{2}{|c|}{ Adsorption inhibition $(\%)^{\mathrm{c}}$} \\
\hline $\mathrm{Cr}$ & $\mathrm{Cu}$ & $\mathrm{Cr}$ & $\mathrm{Cu}$ & & & $\mathrm{Cr}$ & $\mathrm{Cu}$ \\
\hline 20 & 20 & $17.2 \pm 0.7$ & $11.8 \pm 0.6$ & 1.00 & 1.46 & 6.4 & 35.8 \\
\hline 20 & 40 & $16.5 \pm 0.9$ & $16.5 \pm 0.8$ & 0.50 & 1.00 & 10.2 & 48.4 \\
\hline 20 & 60 & $15 \pm 1$ & $17.4 \pm 1.0$ & 0.33 & 0.86 & 18.6 & 57.4 \\
\hline 40 & 20 & $33 \pm 2$ & $10.8 \pm 0.5$ & 2.00 & 3.07 & 9.0 & 41.2 \\
\hline 40 & 40 & $32 \pm 2$ & $15.4 \pm 0.6$ & 1.00 & 2.09 & 11.7 & 51.9 \\
\hline 40 & 60 & $29 \pm 1$ & $16.6 \pm 0.8$ & 0.67 & 1.75 & 20.1 & 59.3 \\
\hline 60 & 20 & $49 \pm 2$ & $9.4 \pm 0.5$ & 3.00 & 5.14 & 10.0 & 48.6 \\
\hline 60 & 40 & $45 \pm 2$ & $12 \pm 0.6$ & 1.50 & 3.64 & 17.2 & 61.6 \\
\hline 60 & 60 & $40 \pm 2$ & $12.9 \pm 0.8$ & 1.00 & 3.13 & 25.5 & 68.5 \\
\hline
\end{tabular}

Adsorbed amounts of $\mathrm{Cr}$ and $\mathrm{Cu}$ are the average of at least three different replicates $(n=3)$

${ }^{\mathrm{a}} R_{i}$ stands for the $\mathrm{Cr} / \mathrm{Cu}$ molar ratio initially added on biochar samples

${ }^{\mathrm{b}} R_{f}$ indicates the $\mathrm{Cr} / \mathrm{Cu}$ molar ratio finally adsorbed on biochar surface

${ }^{\mathrm{c}}$ Inhibition (\%) of $\mathrm{Cr}$ or $\mathrm{Cu}$ adsorption was calculated by subtracting the amount of $\mathrm{Cr}$ or $\mathrm{Cu}$ adsorbed in presence of the other metal from that adsorbed in the absence of the other metal, divided by the amount adsorbed in the absence of the other metal, multiplied per 100

produces a biochar with a small amount of alkyl components and a main aromatic moiety. However, the FT-IR spectrum of our biochar shows that the pore surface contains some polar molecular groups (Table 1). In fact, the bands at 3,546, 3,470, 3,413 , and $1,637 \mathrm{~cm}^{-1}$ are due to the presence of unsubstituted $\left(3,546 \mathrm{~cm}^{-1}\right)$, mono-substituted $\left(3,470 \mathrm{~cm}^{-1}\right)$ and disubstituted $\left(1,637 \mathrm{~cm}^{-1}\right)$ amides, and to $\mathrm{NH}$ stretching of amine groups $\left(3413 \mathrm{~cm}^{-1}\right)$. Presence of oxygenated functions has been also observed. The O-containing groups produced bands at 1,617 and $1,400 \mathrm{~cm}^{-1}$, due to unprotonated carboxyls, and at $1,126 \mathrm{~cm}^{-1}$, due to oxygenated C (C-O). As already reported by Conte et al. (2014), polar groups may affect water dynamics on the surface of biochar due to formation of both conventional and non-conventional hydrogen bonds (see below).

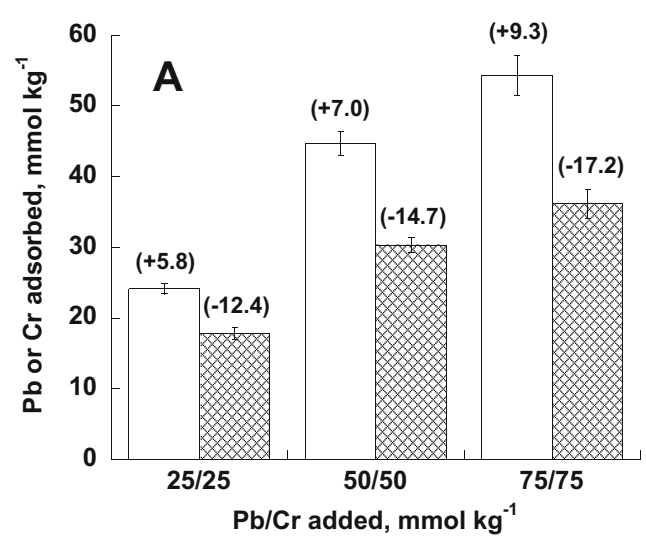

Fig. 6 Effect of residence time on $\mathrm{Pb}$ (white bars) and $\mathrm{Cr}$ (grid bars) adsorption on biochar. $\mathrm{In} \mathbf{a}, \mathrm{Pb}$ was added $1 \mathrm{~h}$ before $\mathrm{Cr}$ on biochar, then the metal mixture was incubated with biochar for $5 \mathrm{~h}$ at $\mathrm{pH} 4.5$ and $20^{\circ} \mathrm{C}$, while the opposite was done in $\mathbf{b}$. The bars are the average of at least three

\section{${ }^{1} \mathrm{H}$ NMR relaxometry}

Figure 1 reports the relaxogram of the biochar sample resolved in three components according to $T_{1}$ values of 86 , 227 , and $316 \mathrm{~ms}$, respectively, which represent the shorter, the intermediate, and the longest $T_{1}$ values, respectively. As previously reported (Conte et al. 2014), the fastest $T_{1}$ value (at $86 \mathrm{~ms}$ ) can be attributed to water molecules located in residual pores $(<0.5 \mu \mathrm{m})$, the intermediate $T_{1}$ value (at $227 \mathrm{~ms}$ ) to water molecules moving in storage pores $(0.5-50 \mu \mathrm{m})$, and the longest $T_{1}$ value (at $316 \mathrm{~ms}$ ) to water moving rapidly within the transmission pores $(\geq 50 \mu \mathrm{m})$. As $\mathrm{Cu}, \mathrm{Cr}$, and $\mathrm{Pb}$ (either sole or in combination) are adsorbed on the surface of the biochar, a change in the distribution of relaxation times is

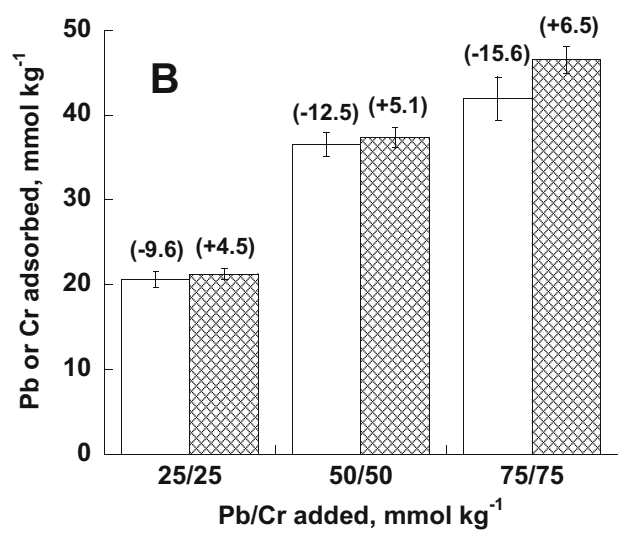

different replicates $(n=3)$. Values in brackets are the percent change of $\mathrm{Pb}$ and $\mathrm{Cr}$ adsorption on biochar vs. the adsorbed amounts of two metals by a simultaneous addition (as shown in Table 3) 


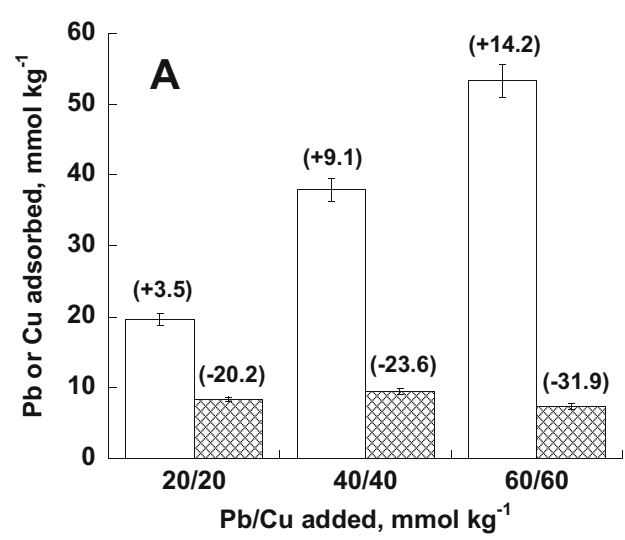

Fig. 7 Effect of residence time on $\mathrm{Pb}$ (white bars) and $\mathrm{Cu}$ (grid bars) adsorption on biochar. $\mathrm{In} \mathbf{a}, \mathrm{Pb}$ was added $1 \mathrm{~h}$ before $\mathrm{Cu}$ on biochar, then the metal mixture was incubated with biochar for $5 \mathrm{~h}$ at $\mathrm{pH} 4.5$ and $20^{\circ} \mathrm{C}$, while the opposite was done in $\mathbf{b}$. The bars are the average of at least three

observed. After $\mathrm{Cu}$ adsorption, the main relaxometry band is centered at a $T_{1}$ value of $52 \mathrm{~ms}$, which is shorter than that observed for the sole biochar (i.e., $238 \mathrm{~ms}$ ) (Fig. 2a). Reduction of $T_{1}$ is due to $\mathrm{Cu}$ paramagnetism. In fact, paramagnetism fastens nuclear relaxation with currents generated by unpaired electrons. However, as for the sole biochar, the deconvolution of the relaxogram in Fig. 2a revealed three type of water movements, occurring in residual $\left(T_{1}=22 \mathrm{~ms}\right)$, storage $\left(T_{1}=43 \mathrm{~ms}\right)$, and transmission $\left(T_{1}=59 \mathrm{~ms}\right)$ pores, respectively. Conceivably, the similarity among the number of relaxometry components in Figs. 1 and 2a indicates that $\mathrm{Cu}$ was homogeneously distributed within the three kinds of pores on the biochar surface. In the case of $\mathrm{Cr}$ application, the relaxograms showed two $T_{1}$ values (Fig. 2b). The shortest $T_{1}$ value $(25 \mathrm{~ms})$ can be attributed to $\mathrm{Cr}$ ions adsorbed into the residual pores. Conversely, most of the $\mathrm{Cr}$ ions were present into storage and transmission pores, thereby shrinking two water movement components into only one centered at $T_{1}$ value of $60 \mathrm{~ms}$. In the case of $\mathrm{Pb}$ application (Fig. 2c), only

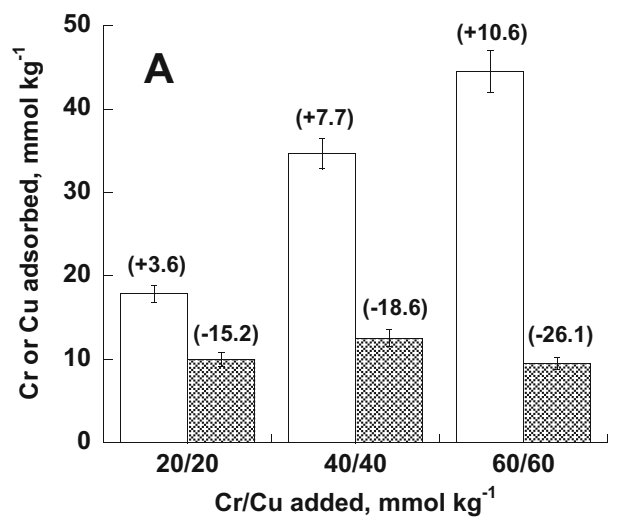

Fig. 8 Effect of residence time on $\mathrm{Cr}$ (white bars) and $\mathrm{Cu}$ (grid bars) adsorption on biochar. $\mathrm{In}$ a $\mathrm{Cr}$ was added $1 \mathrm{~h}$ before $\mathrm{Cu}$ on biochar, then the metal mixture was incubated with biochar for $5 \mathrm{~h}$ at $\mathrm{pH} 4.5$ and $20^{\circ} \mathrm{C}$, while the opposite was done in $\mathbf{b}$. The bars are the average of at least three

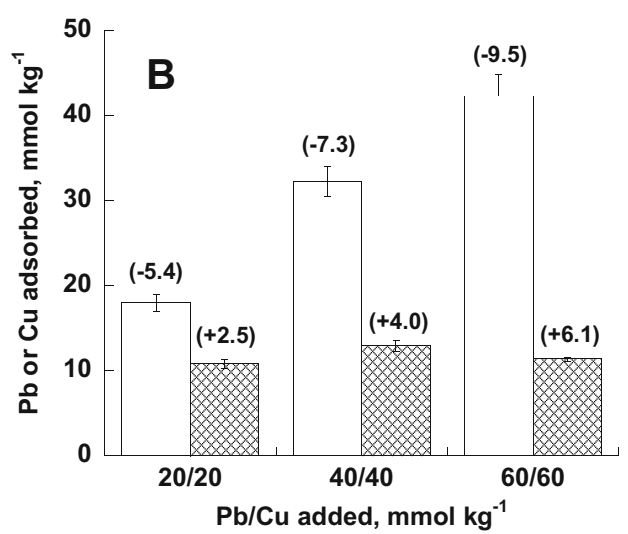

different replicates $(n=3)$. Values in brackets are the percent change of $\mathrm{Pb}$ and $\mathrm{Cu}$ adsorption on biochar vs. the adsorbed amounts of two metals by a simultaneous addition (as shown in Table 4)

a $T_{1}$ value of $71 \mathrm{~ms}$ was observed, probably due to a homogeneous distribution of $\mathrm{Pb}$ into all the three kinds of pores. In particular, water movement resulted unaffected by pore size distribution, but it was only affected by the homogeneous $\mathrm{Pb}$ layer covering the whole biochar surface.

In the case of application of two metals (i.e., $\mathrm{Cu}+\mathrm{Cr}, \mathrm{Cr}+$ $\mathrm{Pb}$, and $\mathrm{Cu}+\mathrm{Pb}$ ), relaxogram shapes differed from those previously discussed. The application of $\mathrm{Cu}$ and $\mathrm{Cr}$ gave a major water movement component centered at around $60 \mathrm{~ms}$ together with two small bands at 19 and $198 \mathrm{~ms}$, respectively (Fig. 3a). This can be attributed to water moving into residual $\left(T_{1}=19 \mathrm{~ms}\right)$, storage $\left(T_{1}=60 \mathrm{~ms}\right)$, and transmission $\left(T_{1}=198 \mathrm{~ms}\right)$ pores. Since the major component at $60 \mathrm{~ms}$ was also shown by using $\mathrm{Cr}$ alone, probably the effect of $\mathrm{Cr}$ adsorption predominated over that of $\mathrm{Cu}$ adsorption on biochar surface. As $\mathrm{Cr}$ was combined with $\mathrm{Pb}$, the relaxogram (Fig. 3b) showed three components again due to water moving in residual $\left(T_{1}=16 \mathrm{~ms}\right)$, storage $\left(T_{1}=50 \mathrm{~ms}\right)$, and transmission $\left(T_{1}=79 \mathrm{~ms}\right)$ pores. This indicates that probably there was no

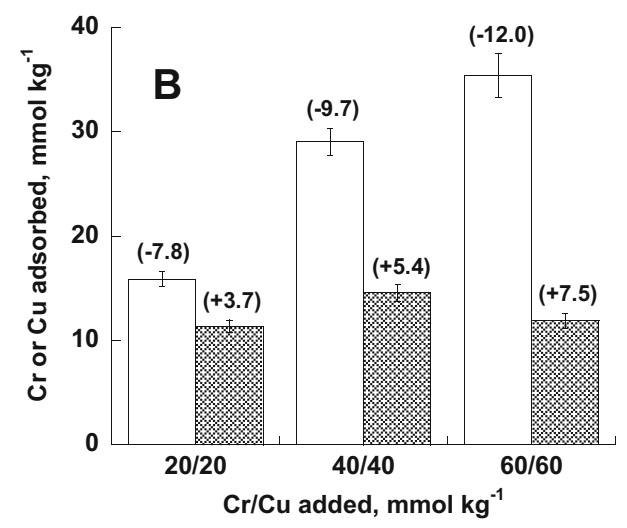

different replicates $(n=3)$. Values in brackets are the percent change of $\mathrm{Cr}$ and $\mathrm{Cu}$ adsorption on biochar vs. the adsorbed amounts of two metals by a simultaneous addition (as shown in Table 5) 
Table 6 Competitive adsorption of $\mathrm{Pb}, \mathrm{Cr}$, and $\mathrm{Cu}$ on biochar at $\mathrm{pH} 4.5$ and $20^{\circ} \mathrm{C}$, after $5 \mathrm{~h}$ of incubation

\begin{tabular}{|c|c|c|c|c|c|c|c|c|c|c|c|}
\hline \multicolumn{3}{|c|}{ Added amounts ( $\mathrm{mmol} \mathrm{kg}^{-1}$ ) } & \multicolumn{3}{|c|}{ Adsorbed amounts (mmol kg-1) } & \multicolumn{3}{|c|}{ Partition of adsorbing surface $(\%)^{\mathrm{a}}$} & \multicolumn{3}{|c|}{ Adsorption inhibition (\%) } \\
\hline $\mathrm{Pb}$ & $\mathrm{Cr}$ & $\mathrm{Cu}$ & $\mathrm{Pb}$ & $\mathrm{Cr}$ & $\mathrm{Cu}$ & $\mathrm{Pb}$ & $\mathrm{Cr}$ & $\mathrm{Cu}$ & $\mathrm{Pb}$ & $\mathrm{Cr}$ & $\mathrm{Cu}$ \\
\hline 20 & 20 & 20 & $15.5 \pm 0.9$ & $13.0 \pm 0.9$ & $8.1 \pm 0.5$ & 42.3 & 35.5 & 22.2 & 21.9 & 29.4 & 55.9 \\
\hline 40 & 40 & 40 & $25 \pm 1$ & $20 \pm 1$ & $9.5 \pm 0.5$ & 46.1 & 36.5 & 17.4 & 36.4 & 45.4 & 70.4 \\
\hline 60 & 60 & 60 & $30 \pm 1$ & $22 \pm 1$ & $4.3 \pm 0.3$ & 53.6 & 38.6 & 7.8 & 49.8 & 60.6 & 89.4 \\
\hline 40 & 20 & 20 & $29 \pm 1$ & $11.1 \pm 0.8$ & $5.6 \pm 0.3$ & 63.0 & 24.5 & 12.5 & 27.5 & 39.8 & 69.3 \\
\hline 60 & 20 & 20 & $36 \pm 2$ & $9.0 \pm 0.6$ & $3.2 \pm 0.2$ & 74.6 & 18.7 & 6.7 & 39.0 & 50.9 & 82.5 \\
\hline 20 & 40 & 20 & $14.6 \pm 0.8$ & $22 \pm 1$ & $7.0 \pm 0.4$ & 33.5 & 50.5 & 16.0 & 26.2 & 39.4 & 62.1 \\
\hline 20 & 60 & 20 & $12.7 \pm 0.7$ & $26 \pm 1$ & $4.7 \pm 0.3$ & 29.4 & 59.7 & 10.9 & 35.7 & 52.0 & 74.4 \\
\hline 20 & 20 & 40 & $15.1 \pm 0.8$ & $12.2 \pm 0.6$ & $10.6 \pm 0.6$ & 39.8 & 32.2 & 28.0 & 23.7 & 33.6 & 66.8 \\
\hline 20 & 20 & 60 & $14.4 \pm 0.7$ & $10.9 \pm 0.6$ & $10.1 \pm 0.6$ & 40.6 & 30.9 & 28.5 & 27.5 & 40.8 & 75.3 \\
\hline
\end{tabular}

Adsorbed amounts of $\mathrm{Pb}, \mathrm{Cr}$ and $\mathrm{Cu}$ are the average of at least three different replicates $(n=3)$

${ }^{a}$ Partition of adsorbing surface by $\mathrm{Pb}, \mathrm{Cr}$, or $\mathrm{Cu}$ was calculated by subtracting the adsorbed amount of $\mathrm{Pb}, \mathrm{Cr}$, or $\mathrm{Cu}$ from the total amount of three metals adsorbed by biochar $(\mathrm{Pb}+\mathrm{Cr}+\mathrm{Cu})$, divided by the total amount of three metals adsorbed by biochar $(\mathrm{Pb}+\mathrm{Cr}+\mathrm{Cu})$, multiplied per 100

${ }^{\mathrm{b}}$ Inhibition (\%) of $\mathrm{Pb}, \mathrm{Cr}$, or $\mathrm{Cu}$ adsorption was calculated by subtracting the amount of $\mathrm{Pb}, \mathrm{Cr}$, or $\mathrm{Cu}$ adsorbed in presence of the other two metals from that adsorbed in the absence of the other two metals, divided by the amount adsorbed in the absence of the other two metals, multiplied per 100

competition between $\mathrm{Pb}$ and $\mathrm{Cr}$ for adsorption on biochar sites. In the case of $\mathrm{Cu}$ and $\mathrm{Pb}$ application, a very broad and intense component was observed at 51 ms together with a negligible component at $21 \mathrm{~ms}$ (Fig. 3c). The predominant band at $51 \mathrm{~ms}$ indicates that $\mathrm{Pb}$ was preferentially adsorbed on the biochar surface. However, the fact that this value was shorter than that reported in Fig. $2 \mathrm{c}$ indicates that also paramagnetic $\mathrm{Cu}$ contributes to water relaxation. The ${ }^{1} \mathrm{H}$ NMR relaxogram obtained by experiments done on the biochar treated with three metals only showed one band placed at $38 \mathrm{~ms}$ (Fig. 4). Our hypothesis is that $\mathrm{Pb}$ was predominantly adsorbed on biochar surface, with a paramagnetic effect due to $\mathrm{Cu}$ which shifts the band to the very short $T_{1}$ value.

\section{Adsorption properties of biochar}

The shape of $\mathrm{Pb}$ and $\mathrm{Cr}$ adsorption isotherms indicated a high affinity behavior (H-type), while the $\mathrm{Cu}$ isotherm revealed a lower affinity for biochar surface (L-type) (Fig. 5). The Langmuir $K$ values obtained from three isotherms (Table 2) also confirmed the high affinity of $\mathrm{Pb}$ and $\mathrm{Cr}$ for biochar adsorption sites $(\mathrm{Pb}>\mathrm{Cr})$, followed by $\mathrm{Cu}$. Greater $K$ values, in fact, indicate higher affinity of the adsorbent for solutes (Sparks 2002). However, in spite of the significant difference in the binding energies ( $K$ values), the maximum $\mathrm{Pb}$ and $\mathrm{Cr}$ adsorption capacities $\left(S_{m}\right)$ were quite similar (108.2 and $98.3 \mathrm{mmol} \mathrm{kg}^{-1}$, respectively), much higher than that obtained from $\mathrm{Cu}$ isotherm $\left(46.5 \mathrm{mmol} \mathrm{kg}^{-1}\right.$ ) (Table 2). The higher adsorption of $\mathrm{Pb}$ than $\mathrm{Cr}$ and $\mathrm{Cu}$ by biochar may be due to the stronger surface electrostatic attraction, since the electronegativity constant of $\mathrm{Pb}$ is quite high (2.33) and this is responsible for specific $\mathrm{Pb}$ adsorption (Inyang et al. 2012). However, the electronegativity constants of $\mathrm{Cr}$ and $\mathrm{Cu}$ are 1.90 and 1.66, respectively, and these values do not explain the heavy metal removal trend $(\mathrm{Pb}>\mathrm{Cr} \gg \mathrm{Cu})$ observed using this biochar as an adsorbent. Chromium has a higher charge density than $\mathrm{Cu}$; hence, the coulombic attraction toward the superficial sites of the adsorbent is higher (Shi et al. 2009). However, in addition to the surface electrostatic interaction, other mechanisms (e.g., surface complexation) can be involved in the ion adsorption (Uchimiya et al. 2011; Inyang et al. 2012). Indeed, the quantity of the adsorbed ions on the adsorbing surface is also strongly affected by other factors, such as the ionic potential, radius of the hydrated ion, and hydrolysis constant (Shi et al. 2009; Zhu et al. 2010). The higher sorption of $\mathrm{Cr}$ than $\mathrm{Cu}$ by our biochar may be also due to the higher first hydrolysis constant of $\mathrm{Cr}\left(10^{-4}\right)$ than $\mathrm{Cu}\left(10^{-8}\right)$. The acidic conditions (pH 4.5) of our experiments may have played an important role on the metal adsorption. For instance, $\mathrm{Cr}$ adsorption by seven sludge-derived biochars was $\mathrm{pH}$-dependent at $\mathrm{pH}$ values of 2.0-5.0, with a maximum adsorption at $\mathrm{pH} 2.0$ (Zhang et al. 2013). The pH-dependent $\mathrm{Cr}$ adsorption on biochar was also shown by others (Demirbas et al. 2004; Dong et al. 2011; Mohan et al. 2011). Zhang et al. (2013) also noted that the highest $\mathrm{Pb}$ adsorption on seven biochars occurred at $\mathrm{pH} 5.0$, a value similar to that of our experiments (i.e., 4.5); moreover, these authors showed that $\mathrm{Pb}$ adsorption was stronger than that of $\mathrm{Cr}$, by comparing the shape of the adsorption isotherms of $\mathrm{Pb}$ (at $\mathrm{pH} 5.0$ ) and $\mathrm{Cr}$ (at $\mathrm{pH} 2.0$ ). A previous study (Xu et al. 2013) revealed that $\mathrm{Cu}$ removal by dairy manure-derived biochar from aqueous solutions was mainly attributed to the formation of $\mathrm{Cu}$ phosphate and $\mathrm{Cu}$ carbonate precipitates. The release of anions as phosphate and carbonate from biochar, able to precipitate heavy metals, can 
cause additional metal disappearance from the solute (Uchimiya et al. 2010). However, since $\mathrm{Cu}$ adsorption on our biochar occurred at $\mathrm{pH} 4.5$, we assume that $\mathrm{Cu}$ precipitation, due to release of phosphate and carbonate ions from biochar, was probably negligible; this hypothesis can, at least in part, explain the low $\mathrm{Cu}$ removal by biochar from solutions. $\mathrm{A}$ much higher removal of $\mathrm{Pb}$ than $\mathrm{Cu}$ by biochar was observed with digested dairy waste biochar, digested whole sugar beet biochar (Inyang et al. 2012), and poultry litterderived biochar (Uchimiya et al. 2010) used as adsorbents. The competitive adsorption of $\mathrm{Pb}, \mathrm{Cr}$, and $\mathrm{Cu}$ on biochar was mainly influenced by the affinity of metals for biochar surface. The higher the affinity, the higher the ability of the metal to occupy adsorption sites. The slight increase of the final $\mathrm{Pb} / \mathrm{Cr}$ molar ratio $\left(R_{f}\right)$ in comparison with the initial molar ratio $\left(R_{i}\right)$ revealed that $\mathrm{Pb}$ was able to prevent more efficiently the $\mathrm{Cr}$ adsorption on biochar than $\mathrm{Cr}$ in preventing $\mathrm{Pb}$ adsorption. $\mathrm{A}$ significantly higher increase of $R_{f}$ vs. $R_{i}$ was obtained in the $\mathrm{Cr}-\mathrm{Cu}$ binary system (Table 5) and, even more, in the $\mathrm{Pb}-\mathrm{Cu}$ binary system (Table 4 ), where $R_{f}$ resulted to be up to threefold (in the former case) and fourfold (in the latter case) higher than $R_{i}$, because of the much higher affinity of $\mathrm{Pb}$ and $\mathrm{Cr}$ than $\mathrm{Cu}$ for biochar adsorption sites. Our findings agree with those by Chen et al. (2011), who found that $\mathrm{Cu}$ inhibited $\mathrm{Zn}$ removal by hardwood-derived and corn-straw-derived biochars, because of the higher affinity of the former than the latter metal for adsorption sites of two adsorbents. We have also found that an increase in residence time of each metal on the biochar surface increased the adsorption of the metal if compared to that observed by the simultaneous addition with another metal, probably because of the better diffusion inside the adsorbent structure and formation of stronger bonds between metal and biochar adsorption sites during the pre-equilibration phase. A similar trend was found by Zhu et al. (2010), in a competitive study of $\mathrm{Pb}, \mathrm{Cr}$, and $\mathrm{Cu}$ adsorption on ferrihydrite and two organomineral complexes.

\section{Conclusions}

This study provided important information regarding the potential use of biochar as adsorbent of heavy metals, such as $\mathrm{Pb}$, $\mathrm{Cr}$, and $\mathrm{Cu}$, from aqueous mono- and multi-contaminated environments. Biomass-derived biochar combines an effective removal of water contaminants with low costs of remediation. The water movement on the biochar pores was affected by metal adsorption, as shown by FFC NMR relaxometry, which is a novel and promising technique to identify the nature of biochar-metal bonds at the solid-liquid interface. However, more studies are needed to demonstrate the feasibility of biochar as adsorbent for an effective and safe removal of heavy metals from contaminated waters in situ.
Acknowledgments The authors wish to acknowledge the Institute of Biometeorology (IBIMET), National Research Council (CNR) of Florence, Italy, and, in particular, Dr. Silvia Baronti, who kindly offered the biochar applied in the present study. This work was supported by the Italian Research Program of National Interest (PRIN 2010-2011).

\section{References}

Baronti S, Vaccari FP, Miglietta F, Calzolari C, Lugato E, Orlandini S, Pini R, Zulian C, Genesio L (2014) Impact of biochar application on plant water relations in Vitis vinifera (L.). Eur J Agron 53:38-44. doi:10.1016/j.eja.2013.11.003

Beesley L, Marmiroli M (2011) The immobilisation and retention of soluble arsenic, cadmium and zinc by biochar. Environ Pollut 159: 474-480. doi:10.1016/j.envpol.2010.10.016

Cao XD, Ma LN, Gao B, Harris W (2009) Dairy-manure derived biochar effectively sorbs lead and atrazine. Environ Sci Technol 43:32853291. doi:10.1021/Es803092k

Castaldi S, Riondino M, Baronti S, Esposito FR, Marzaioli R, Rutigliano FA, Vaccari FP, Miglietta F (2011) Impact of biochar application to a Mediterranean wheat crop on soil microbial activity and greenhouse gas fluxes. Chemosphere 85:1464-1471. doi:10.1016/j. chemosphere.2011.08.031

Chen XC, Chen GC, Chen LG, Chen YX, Lehmann J, McBride MB, Hay AG (2011) Adsorption of copper and zinc by biochars produced from pyrolysis of hardwood and corn straw in aqueous solution. Bioresour Technol 102:8877-8884. doi:10.1016/j.biortech.2011.06.078

Cimò G, Kucerik J, Berns AE, Schaumann GE, Alonzo G, Conte P (2014) Effect of heating time and temperature on the chemical characteristics of biochar from poultry manure. J Agric Food Chem 62:1912-1918. doi:10.1021/Jf405549z

Conte P, Alonzo G (2013) Environmental NMR: fast-field-cycling relaxometry. eMagRes 2:389-398. doi:10.1002/9780470034590. emrstm1330

Conte P, Marsala V, De Pasquale C, Bubici S, Valagussa M, Pozzi A, Alonzo G (2013) Nature of water-biochar interface interactions. GCB Bioenergy 5:116-121. doi:10.1111/Gcbb.12009

Conte P, Hanke UM, Marsala V, Cimò G, Alonzo G, Glaser B (2014) Mechanisms of water interaction with pore systems of hydrochar and pyrochar from poplar forestry waste. J Agric Food Chem 62: 4917-4923. doi:10.1021/Jf5010034

De Pasquale C, Marsala V, Berns AE, Valagussa M, Pozzi A, Alonzo G, Conte P (2012) Fast field cycling NMR relaxometry characterization of biochars obtained from an industrial thermochemical process. J Soils Sediments 12:1211-1221. doi:10.1007/s11368-012-0489-x

Demirbas E, Kobya M, Senturk E, Ozkan T (2004) Adsorption kinetics for the removal of chromium (VI) from aqueous solutions on the activated carbons prepared from agricultural wastes. Water SA 30 : 533-539

Dong XL, Ma LNQ, Li YC (2011) Characteristics and mechanisms of hexavalent chromium removal by biochar from sugar beet tailing. $\mathrm{J}$ Hazard Mater 190:909-915. doi:10.1016/j.jhazmat.2011.04.008

Farrell M, Macdonald LM, Butler G, Chirino-Valle I, Condron LM (2014) Biochar and fertiliser applications influence phosphorus fractionation and wheat yield. Biol Fertil Soils 50:169-178. doi: 10.1007/s00374-013-0845-Z

Fellet G, Marchiol L, Delle Vedove G, Peressotti A (2011) Application of biochar on mine tailings: effects and perspectives for land reclamation. Chemosphere 83:1262-1267. doi:10.1016/j.chemosphere. 2011.03.053

Hsu NH, Wang SL, Lin YC, Sheng GD, Lee JF (2009) Reduction of $\mathrm{Cr}(\mathrm{VI})$ by crop-residue-derived black carbon. Environ Sci Technol 43:8801-8806. doi:10.1021/Es901872x 
Inyang M, Gao B, Yao Y, Xue YW, Zimmerman AR, Pullammanappallil P, Cao XD (2012) Removal of heavy metals from aqueous solution by biochars derived from anaerobically digested biomass. Bioresour Technol 110:50-56. doi:10.1016/j.biortech.2012.01.072

Jiang J, Xu RK, Jiang TY, Li Z (2012a) Immobilization of Cu(II), Pb(II) and $\mathrm{Cd}(\mathrm{II})$ by the addition of rice straw derived biochar to a simulated polluted Ultisol. J Hazard Mater 229:145-150. doi:10.1016/j. jhazmat.2012.05.086

Jiang TY, Jiang J, Xu RK, Li Z (2012b) Adsorption of Pb(II) on variable charge soils amended with rice-straw derived biochar. Chemosphere 89:249-256. doi:10.1016/j.chemosphere.2012.04.028

Kammann CI, Linsel S, Gossling JW, Koyro HW (2011) Influence of biochar on drought tolerance of Chenopodium quinoa Willd and on soil-plant relations. Plant Soil 345:195-210. doi:10.1007/s11104011-0771-5

Laird DA (2008) The charcoal vision: a win-win-win scenario for simultaneously producing bioenergy, permanently sequestering carbon, while improving soil and water quality. Agron J 100:178-181. doi: 10.2134/agronj2007.0161

Laird D, Fleming P, Wang BQ, Horton R, Karlen D (2010) Biochar impact on nutrient leaching from a Midwestern agricultural soil. Geoderma 158:436-442. doi:10.1016/j.geoderma.2010.05.012

Lehmann J (2007a) Bio-energy in the black. Front Ecol Environ 5:381387. doi:10.1890/1540-9295(2007)5[381:Bitb]2.0.Co;2

Lehmann J (2007b) A handful of carbon. Nature 447:143-144. doi: $10.1038 / 447143 a$

Lehmann J, Skjemstad J, Sohi S, Carter J, Barson M, Falloon P, Coleman K, Woodbury P, Krull E (2008) Australian climate-carbon cycle feedback reduced by soil black carbon. Nat Geosci 1:832-835. doi:10.1038/Ngeo358

Li M, Liu Q, Guo LJ, Zhang YP, Lou ZJ, Wang Y, Qian GR (2013) Cu(II) removal from aqueous solution by Spartina alterniflora derived biochar. Bioresour Technol 141:83-88. doi:10.1016/j.biortech. 2012.12.096

Liu ZG, Zhang FS (2009) Removal of lead from water using biochars prepared from hydrothermal liquefaction of biomass. J Hazard Mater 167:933-939. doi:10.1016/j.jhazmat.2009.01.085

Lu HL, Zhang WH, Yang YX, Huang XF, Wang SZ, Qiu RL (2012) Relative distribution of $\mathrm{Pb}^{2+}$ sorption mechanisms by sludgederived biochar. Water Res 46:854-862. doi:10.1016/j.watres. 2011.11.058

Major J, Rondon M, Molina D, Riha SJ, Lehmann J (2010) Maize yield and nutrition during 4 years after biochar application to a Colombian savanna oxisol. Plant Soil 333:117-128. doi:10. 1007/s11104-010-0327-0

Mohan D, Pittman CU, Bricka M, Smith F, Yancey B, Mohammad J, Steele PH, Alexandre-Franco MF, Gomez-Serrano V, Gong H (2007) Sorption of arsenic, cadmium, and lead by chars produced from fast pyrolysis of wood and bark during bio-oil production. $\mathrm{J}$ Colloid Interface Sci 310:57-73. doi:10.1016/j.jcis.2007.01.020

Mohan D, Rajput S, Singh VK, Steele PH, Pittman CU (2011) Modeling and evaluation of chromium remediation from water using low cost bio-char, a green adsorbent. J Hazard Mater 188:319-333. doi:10. 1016/j.jhazmat.2011.01.127

Prayogo C, Jones JE, Baeyens J, Bending GD (2014) Impact of biochar on mineralisation of $\mathrm{C}$ and $\mathrm{N}$ from soil and willow litter and its relationship with microbial community biomass and structure. Biol Fertil Soils 50:695-702. doi:10.1007/s00374-013-0884-5
Qiu YP, Cheng HY, Xu C, Sheng D (2008) Surface characteristics of crop-residue-derived black carbon and lead(II) adsorption. Water Res 42:567-574. doi:10.1016/j.watres.2007.07.051

Regmi P, Moscoso JLG, Kumar S, Cao XY, Mao JD, Schafran G (2012) Removal of copper and cadmium from aqueous solution using switchgrass biochar produced via hydrothermal carbonization process. J Environ Manag 109:61-69. doi:10.1016/j.jenvman.2012.04.047

Shen YS, Wang SL, Tzou YM, Yan YY, Kuan WH (2012) Removal of hexavalent $\mathrm{Cr}$ by coconut coir and derived chars - the effect of surface functionality. Bioresour Technol 104:165-172. doi:10. 1016/j.biortech.2011.10.096

Shi TH, Jia SG, Chen Y, Wen YH, Du CM, Guo HL, Wang ZC (2009) Adsorption of $\mathrm{Pb}$ (II), $\mathrm{Cr}$ (III), $\mathrm{Cu}$ (II), $\mathrm{Cd}(\mathrm{II})$ and $\mathrm{Ni}(\mathrm{II})$ onto a vanadium mine tailing from aqueous solution. J Hazard Mater 169:838846. doi:10.1016/j.jhazmat.2009.04.020

Song YJ, Zhang XL, Ma B, Chang SX, Gong J (2014) Biochar addition affected the dynamics of ammonia oxidizers and nitrification in microcosms of a coastal alkaline soil. Biol Fertil Soils 50:321332. doi:10.1007/s00374-013-0857-8

Sparks DL (2002) Environmental soil chemistry. Academic Press, New York

Srivastava NK, Majumder CB (2008) Novel biofiltration methods for the treatment of heavy metals from industrial wastewater. J Hazard Mater 151:1-8. doi:10.1016/j.jhazmat.2007.09.101

Stewart CE, Zheng JY, Botte J, Cotrufo MF (2013) Co-generated fast pyrolysis biochar mitigates green-house gas emissions and increases carbon sequestration in temperate soils. GCB Bioenergy 5:153-164. doi:10.1111/Gcbb.12001

Tong XJ, Li JY, Yuan JH, Xu RK (2011) Adsorption of Cu(II) by biochars generated from three crop straws. Chem Eng J 172:828-834. doi:10. 1016/j.cej.2011.06.069

Uchimiya M, Lima IM, Klasson KT, Chang SC, Wartelle LH, Rodgers JE (2010) Immobilization of heavy metal ions (Cu-II, Cd-II, Ni-II, and $\mathrm{Pb}-\mathrm{II})$ by broiler litter-derived biochars in water and soil. J Agric Food Chem 58:5538-5544. doi:10.1021/Jf9044217

Uchimiya M, Chang S, Klasson KT (2011) Screening biochars for heavy metal retention in soil: role of oxygen functional groups. J Hazard Mater 190:432-441. doi:10.1016/j.jhazmat.2011.03.063

Vaccari FP, Baronti S, Lugato E, Genesio L, Castaldi S, Fornasier F, Miglietta F (2011) Biochar as a strategy to sequester carbon and increase yield in durum wheat. Eur J Agron 34:231-238. doi:10. 1016/j.eja.2011.01.006

Wang XS, Chen LF, Li FY, Chen KL, Wan WY, Tang YJ (2010) Removal of $\mathrm{Cr}$ (VI) with wheat-residue derived black carbon: reaction mechanism and adsorption performance. J Hazard Mater 175:816-822. doi:10.1016/j.jhazmat.2009.10.082

Xu XY, Cao XD, Zhao L, Wang HL, Yu HR, Gao B (2013) Removal of $\mathrm{Cu}, \mathrm{Zn}$, and $\mathrm{Cd}$ from aqueous solutions by the dairy manure-derived biochar. Environ Sci Pollut Res 20:358368. doi:10.1007/s11356-012-0873-5

Zhang WH, Mao SY, Chen H, Huang L, Qiu RL (2013) Pb(II) and Cr(VI) sorption by biochars pyrolyzed from the municipal wastewater sludge under different heating conditions. Bioresour Technol 147: 545-552. doi:10.1016/j.biortech.2013.08.082

Zhu J, Pigna M, Cozzolino V, Caporale AG, Violante A (2010) Competitive sorption of copper(II), chromium(III) and lead(II) on ferrihydrite and two organomineral complexes. Geoderma 159:409_ 416. doi:10.1016/j.geoderma.2010.09.006 